\title{
The Influence of Cigarette Ingredients on Smoking Cessation Rates *
}

\author{
by
}

Matthew Rodger and Adam Slater

Oxford Economics Ltd., Abbey House, 121 St Aldates, Oxford, OX1 1HB, United Kingdom

\section{SUMMARY}

It has been suggested that the common practice of adding ingredients to cigarette tobacco might affect patterns of smoking initiation, consumption or cessation. These suggestions have themselves prompted claims that regulation of such ingredients may contribute to reducing the prevalence of tobacco use and dependence among new and continuing smokers. In order to investigate the evidential basis for such claims, we performed a cross-sectional statistical analysis of smoking quit ratios across a sample of 80 countries, comparing those with high market shares of traditional blended cigarettes and those with high market shares of Virginia-style cigarettes, utilizing the fact that traditional blended cigarettes contain added ingredients whereas Virginia-style cigarettes contain no or very few added ingredients. Our results support the findings of our previous study performed in 2012 (across a sample of 46 countries), showing no evidence that the hypothesised effects exist with regard to quit ratios, and find that the use of ingredients can account for virtually none of the crosscountry variation in quit behaviour. This conclusion is robust to alternative specifications of variables, and to controlling for a variety of socio-economic indicators in a multivariate regression setting. We find socio-economic variables - notably income, education and internet access exert a significant effect on the quit ratio, inducing higher cessation rates as standards in medical care and information improve as societies develop. We also find various tobacco control measures induce high quit ratios across countries. Both of these findings are in line with existing international evidence on smoking patterns. [Beitr. Tabakforsch. Int. 28 (2018) 65-80]

\section{KEY WORDS}

Smoking cessation; tobacco ingredients; Virginia-style cigarettes; traditional blended cigarettes; American blend cigarettes; tobacco control; social and economic variables

\section{ZUSAMMENFASSUNG}

Es wird vermutet, dass die übliche Praxis der Zugabe von aromatisierten Bestandteilen zu Zigarettentabak die Muster der Aufnahme, des Konsums oder der Beendigung des Rauchens beeinflussen könnte. Diese Ansicht hat zu der Behauptung geführt, dass die Regulierung solcher Inhaltsstoffe dazu beitragen kann, die Prävalenz des Tabakkonsums und der -abhängigkeit bei neuen und aktiven Rauchern zu verringern. Um die Relevanz solcher Behauptungen $\mathrm{zu}$ untersuchen, führten wir eine statistische Querschnittsanalyse der Raucherquoten in 80 Ländern durch. Dabei wurden Länder mit hohen Marktanteilen an traditionellen American Blend-Zigaretten und Länder mit hohen Marktanteilen an Zigaretten im Virginia-Stil verglichen. Traditionelle American Blend-Zigaretten enthalten 
zusätzliche Inhaltsstoffe, während Virginia-Zigaretten keine oder sehr wenige zusätzliche Inhaltsstoffe enthalten. Unsere Analyse bestätigt die Ergebnisse unserer früheren Studie aus dem Jahr 2012 (basierend auf Daten aus 46 Ländern): Wir finden keine Hinweise darauf, dass die hypothetischen Effekte in Bezug auf die Quit-Ratios bestehen, und stellen fest, dass die Verwendung von zusätzlichen Inhaltsstoffen nahezu keinen messbaren Einfluss auf die Unterschiede im Quit-Verhalten zwischen den Ländern hat. Diese Schlussfolgerung ist robust gegenüber alternativen Spezifikationen von Variablen sowie dem Einbezug einer Vielzahl sozioökonomischer Kontrollvariablen mit Hilfe einer multivariaten Regression. Im Einklang mit der Literatur stellen wir vielmehr fest, dass erstens das QuitVerhalten stark von sozioökonomischen Variablen, insbesondere Einkommen, Bildung und Internetzugang, abhängig ist. Demnach können bessere Standards im Bereich der medizinischen Versorgung und besserer Informationszugang, beides Indikatoren für gesellschaftliche Entwicklung, die Quit-Ratio erhöhen. Des weiteren zeigt unsere Analyse, dass verschiedene Maßnahmen zur Eindämmung des Tabakkonsums länderübergreifend mit höheren Quit-Ratios verbunden sind. [Beitr. Tabakforsch. Int. 28 (2018) 65-80]

\section{RESUME}

Il a été suggéré que la pratique courante consistant à ajouter des ingrédients au tabac à cigarettes pourrait affecter les modes d'initiation, de consommation ou de renoncement du tabagisme. Ces suggestions ont elles-mêmes suscité des affirmations selon lesquelles la réglementation de ces ingrédients pourrait contribuer à réduire la prévalence de l'usage du tabac et de la dépendance chez les fumeurs nouveaux et habituels. Afin d'enquêter sur la base probante de ces allégations, nous avons effectué une analyse statistique transversale des taux d'abandon du tabagisme de 80 pays, en comparant les pays où les parts de marché de cigarettes "American blend" sont élevées avec ceux où les parts de marché de cigarettes "Virginia" sont élevées, en utilisant le fait que les cigarettes "American blend" contiennent des ingrédients ajoutés alors que les cigarettes "Virginia" ne contiennent pas ou très peu d'ingrédients. Nos résultats soutiennent les résultats de notre étude précédente réalisée en 2012 (dans un échantillon de 46 pays), ne montrant aucune preuve que les effets postulés existent en ce qui concerne les taux d'abandon, et nous constatons que l'utilisations d'ingrédients n'explique quasiment aucune variation des taux d'abandon entre les pays étudiés. Cette conclusion est robuste à l'utilisation d'autres variables dans la spécification du modèle et à la prise en compte d'une variété d'indicateurs socio-économiques dans le cadre de régression multivariée. Nous trouvons des variables socioéconomiques - notamment le revenu, l'éducation et l'accès à Internet - qui exercent un effet significatif sur le taux d'abandon, induisant des taux d'abandon plus élevés à mesure que les normes médicales et informationnelles s'améliorent. Nous constatons également que diverses mesures de lutte contre le tabagisme induisent des ratios de démissions élevés entre les pays. Ces deux constatations sont conformes aux données internationales existantes sur les habitudes tabagiques. [Beitr. Tabakforsch. Int. 28 (2018) 65-80]

\section{INTRODUCTION}

The two most common styles of factory-made white cigarettes are Virginia-style and traditional blended, also known as American blend. Traditional blended cigarettes utilize three different types of tobacco - Virginia, Burley, and Oriental - that are blended together during the manufacturing process, whereas Virginia-style cigarettes contain only flue-cured tobacco. Typically, blended cigarettes have ingredients such as sugars added to replace the sugars lost during the curing of Burley tobacco, and flavours to contribute to the tobacco taste, whereas Virginia-style cigarettes contain few or no added ingredients (1). These added ingredients are a potential problem in two respects: by raising the harm of smoking and by raising the addictiveness of smoking. For the purposes of this study, we focussed on the effects of ingredients on smoking addictiveness, rather than harm.

Different cigarette markets tend to be heavily dominated by one or the other of these two cigarette types - whether a given country is a Virginia market or a traditional blended market is determined largely by historical patterns of consumer preference, and so can reasonably be taken as exogenous. Traditional blended cigarettes are predominant in the U.S., Latin America, most EU Member States, Eastern Europe, and many Asian countries. Virginia-style cigarettes are the most popular brands among smokers in China, many other Asian countries and the Commonwealth countries, including Australia, Canada, the UK, and Ireland. There have been suggestions in recent years that the addition of ingredients to tobacco might affect patterns of smoking initiation, consumption or cessation $(2,13)^{1,2}$. There is little in the way of existing literature directly addressing this hypothesis using cross country comparison, although that which exists tends to find little support for such hypotheses.

SANDERS et al. (12) compared cessation rates of smokers of traditional blended cigarettes to those of smokers of fluecured cigarettes (i.e., those without added ingredients), using data on participants in randomized clinical trials evaluating the effectiveness of nicotine replacement therapy (NRT) intervention. Twenty of the data sets evaluated were from trials conducted in countries where the vast majority of cigarettes smoked are Virginia-style cigarettes (United Kingdom, Australia, New Zealand, and Canada) and 84 data sets were from countries where the predominant style of cigarettes contain added ingredients (the U.S., various continental European countries).

\footnotetext{
1 "Tobacco additives may increase the consumption rate of tobacco products by making the product more palatable and attractive to the consumer, or by enhancing the addictiveness of the product. Additives may make individual brands taste more appealing and mask the taste and immediate discomfort of smoke. As such, additives may indirectly enhance tobacco-related harm by increasing the consumption of these toxic products." - Additives in Tobacco Products, German Cancer Research Centre, 2012, Introduction, p 1.

2 "The attractiveness of tobacco products may be increased by a number of additives. Many different additives are used to create a specific taste/flavour in order to attract certain target groups. An attractive effect may be obtained by changing the appearance of the product and the smoke, decreasing the harshness of the smoke, and inducing a pleasant experience of smoking." - Addictiveness and Attractiveness of Tobacco Additives, European Commission Scientific Committee on Emerging and Newly Identified Health Risks, 2010, Opinion, p 85.
} 
Through analysis of the data they found that "...these results strongly suggest that ingredients used in the manufacture of traditional blended cigarettes do not increase the inherent addictiveness of cigarettes."

Similarly, OXFORD ECONOMICS (8) examined a 46-country sample and found no evidence linking the presence of ingredients in cigarettes to cross-country variations in quit ratios.

Taking a different approach, LEE et al. (6) used crosscountry differences in the prevalence of different cigarette styles to assess the effect of ingredients on health-related outcomes. They compared mortality rates from lung cancer and chronic obstructive pulmonary disease (COPD) in four countries in which traditional blended cigarettes are almost exclusively smoked (Austria, Denmark, Germany, and the United States) and three countries in which flue-cured cigarettes are almost exclusively smoked (Australia, Canada, and the United Kingdom). They concluded that "differences between countries in the rates of two major diseases for which smoking is clearly the predominant cause cannot materially be explained by whether the cigarettes usually smoked in the countries (now and in the past) are flue-cured or blended."

Other than LEE et al. and SANDERS et al. $(6,12)$, most of the existing literature on cross-country smoking behaviour focuses on economic, social and institutional factors, without taking into account differences in types of cigarettes smoked. KEELER et al. (5), ROSS and CHALOUPKA (10) and SUNG et al. (14) all find large effects of the cigarette price on smoking behaviour, while SCHAAP et al. (11) find significant effects of various tobacco control policies. This paper builds upon and updates the OXFORD ECONOMICS 2012 study. We use a sample of 80 countries, gathered on the basis of data availability, to investigate the hypothesis that the presence of ingredients in cigarettes affects smoking cessation behaviour. The main sample is divided into two subsamples according to the dominant variety of cigarette in the sampled country. Figure 1 illustrates the market shares of different cigarette styles across the main sample, with the lowest 62 countries being those classified as traditional blended countries, and the remaining 18 being classified as Virginia-style countries. We first examine raw comparisons in quit ratios between these two subsamples, and then proceed to cross-sectional regressions which allow us to control for socio-economic variables (such as income and education levels) and measures of tobacco control policies (such as public spending on tobacco control). Where relevant, we compare results with the earlier 2012 OXFORD ECONOMICS (8) study.

\section{MATERIALS AND METHODS}

\subsection{Dependent variables}

The principal variable used in this study is the quit ratio, defined as the number of former smokers as a proportion of ever smokers (former smokers plus current smokers). The construction of the quit ratio followed SCHAAP et al. (11) using national health surveys reported by the sampled country, although the lack of requisite data prohibited this ratio being age-standardised. Data on the quit ratio was taken from the latest iteration of the Eurobarometer survey, the WHO and national health surveys (data sources are listed in the appendix). For the majority of countries, 2014 data was used, although where this was not available various historical survey data was used, details of which can be found in Table 4 in the appendix section of this paper. Countries that are newly included in this study, or have new survey data not included in the 2012 study, are also listed in Table 4 in the appendices. The list of countries originally included in the 2012 study can be found in Table 7.

\subsection{Covariates}

The principal covariate of interest is the market share of traditional blended cigarettes by country. This was constructed using data from AC Nielsen provided by Philip Morris International for the 80 countries in our sample. In addition, the use of multivariate regression techniques allowed us to control for a number of social and economic variables that have been identified as influencing smoking behaviour. The first set of regressions used GDP (Gross domestic product) per capita (at purchasing power parity exchange rates and expressed in logarithms ${ }^{3}$ ) sourced from the World Bank and Oxford Economics. Age-standardised smoking prevalence rates from the WHO (16) were also used in these regressions to prevent potential bias arising from differences in the progress of the 'smoking epidemic' between countries. Variables relating to life expectancy, the extent of internet usage and secondary education were also used as control variables - all drawn from the most recent World Bank Development Indicators (17).

We also employed a number of covariates specific to the tobacco market to investigate the role of tobacco control measures. The price of the best-selling cigarette brand in each country - measured at purchasing power parity (PPP) exchange rates - was obtained from the WHO, controlling for differing cigarette taxation policies across sampled countries. Collectively, this data existed for all 80 countries. Following JOOSENS and RAW $(3,4)$ a 'tobacco control' index was developed using data on smoke-free areas, advertising bans, health warnings and cessation programs from the WHO Global Data Repository (16), transforming them into numeric values and combining them into an overall index taking values 0 to 9 by scaling and weighting them. Sufficient data existed for 71 of the countries in our main sample. ${ }^{4}$ Finally, we used data from the WHO and Oxford Economics to construct a rank variable listing countries by their spending on tobacco control as a proportion of GDP. Data existed for 54 of the countries in our main sample. ${ }^{5}$

\footnotetext{
3 Purchasing Power Parity (PPP) exchange rates were used to ensure that the purchasing power of reported income is standardised across the sample. Logarithms are used to ensure we capture relative changes in reported GDP per capita at PPP exchange rates.

4 Excluding Iran, Mexico, Moldova, South Korea, Taiwan, UAE, USA, Venezuela and Vietnam (no data).

5 Excluding Bahrain, Belarus, Costa Rica, Czech Rep, Estonia, Georgia, Greece, Hungary, Ireland, Luxembourg, Malaysia, Morocco, Norway, Panama, Portugal, Russia, Singapore, Spain, Switzerland, Taiwan, Tunisia, UAE, Uganda, Ukraine, Uruguay, UK (no data).
} 


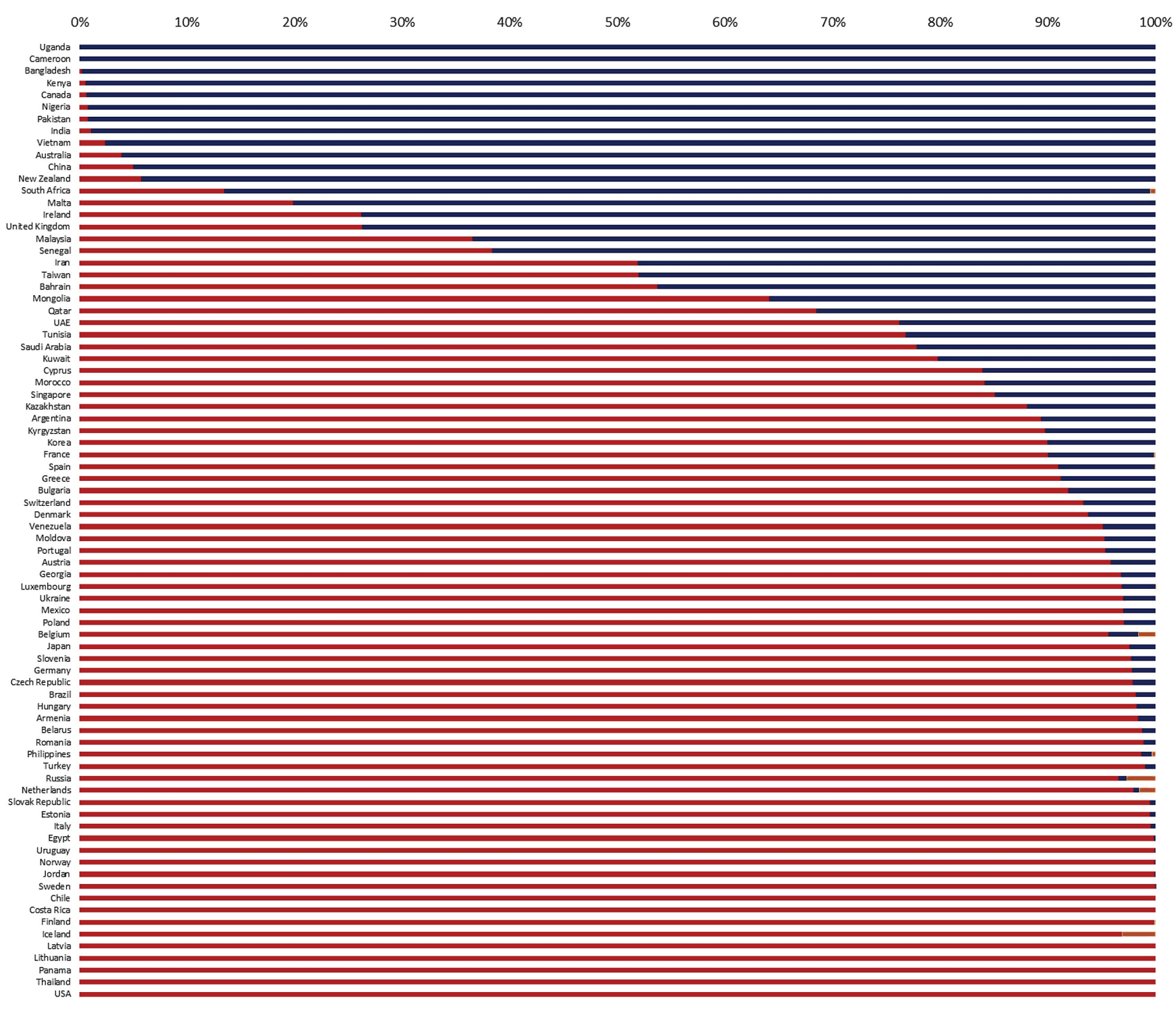

- Share of Traditional Blended $\quad$ Share of Virginia $\quad$ Share of Other and Undefined

Figure 1. Main sample by market share of cigarette variety, 2018 study. 


\subsection{Statistical analysis}

We start the analysis with a direct comparison of quit ratios between countries dominated by traditional blended cigarettes and those dominated by Virginia-style cigarettes. The statistical comparison is made by comparing the average quit ratio in these markets, using a two-sided t-test of the difference to test for statistical significance. The complete results of this analysis can be seen in Section 3 . This direct comparison then moved to bivariate and multivariate regression analysis that controls for country specific factors that may affect the quit ratio. As there was no reason to assume nonlinear relationships between the quit ratio, the blended market share and the control variables, these regressions were all estimated using linear Ordinary Least Squares (OLS) regression. The complete result of this statistical analysis can be seen in Section 4.

\section{RESULTS}

\subsection{Comparison of quit ratios}

Most countries in our sample had a dominant cigarette variety in their domestic market. This allowed us to classify countries as either Virginia-style or traditional blended markets, based on whether the relevant variety of cigarettes sold in the country was greater than $50 \%$ of all cigarettes sold.

As illustrated in Figures $2 \mathrm{a}$ and $2 \mathrm{~b}$, the mean quit ratio was slightly higher in traditional blended markets than in Virginia markets, with a ratio of 0.351 versus 0.343 .

The mean quit ratio in the whole sample was 0.349 . For comparison, Figures $2 \mathrm{c}$ and $2 \mathrm{~d}$ show the (smaller) sample used in the earlier 2012 OXFORD ECONOMICS (8) study. The tables illustrate the differing regional preferences in tobacco use, with Europe dominated by traditional blended cigarettes (with only three Virginia-style markets) and nonEuropean countries featuring a greater number of Virginiastyle markets.

Rudimentary examination of these variables suggests that any relationship between the cigarette variety and quit ratio within the sample is weak.

High quit ratios are observed in both traditional blended markets (Iceland and Sweden) as well as Virginia markets (Canada and New Zealand). Similarly, low quit ratios are observed in a number of both traditional blended markets (Egypt and Russia) and Virginia markets (Pakistan and Bangladesh).

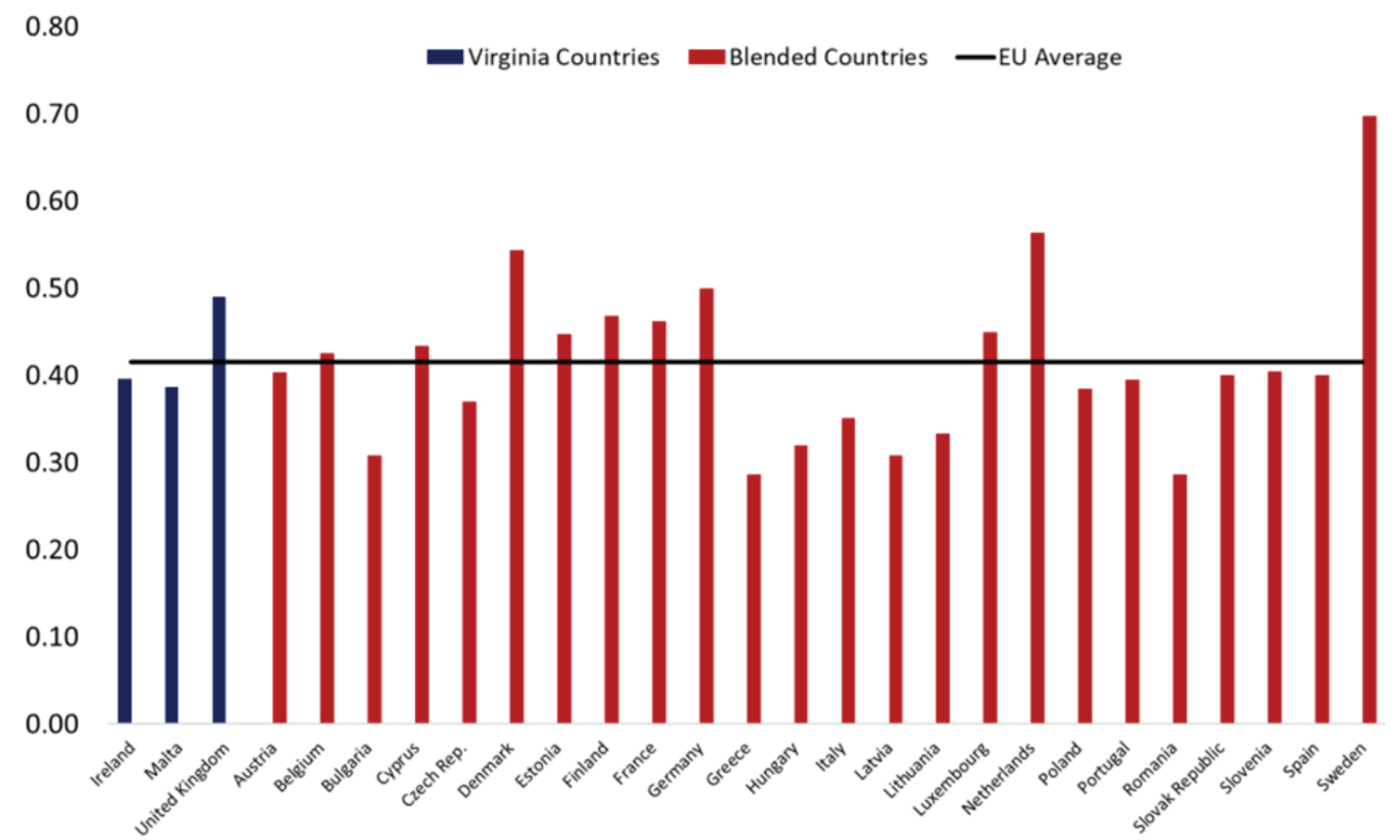

Figure 2a. Quit ratios in EU27 states, 2018 study. 


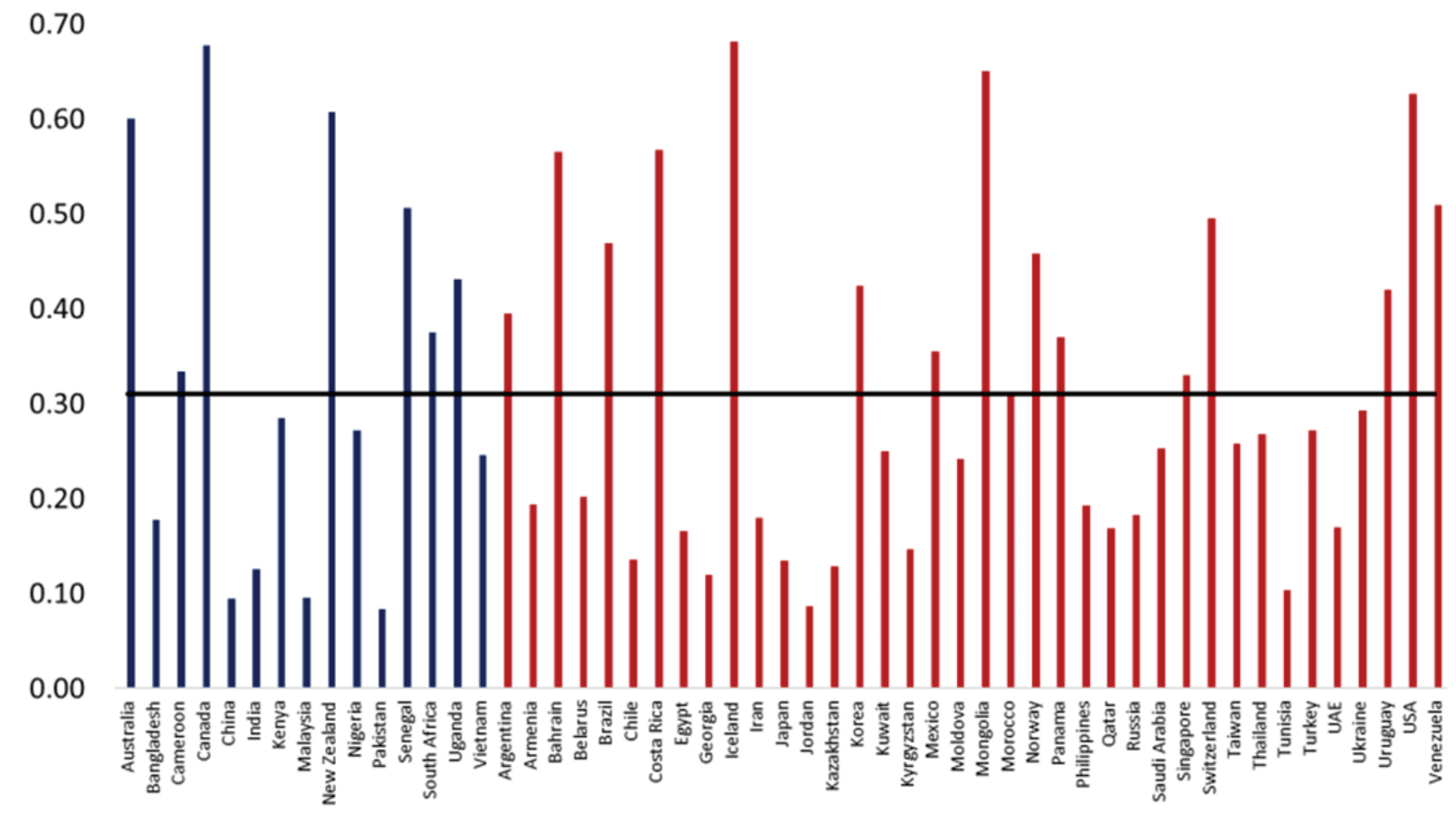

Figure 2b. Quit ratios in non-EU countries, 2018 study.

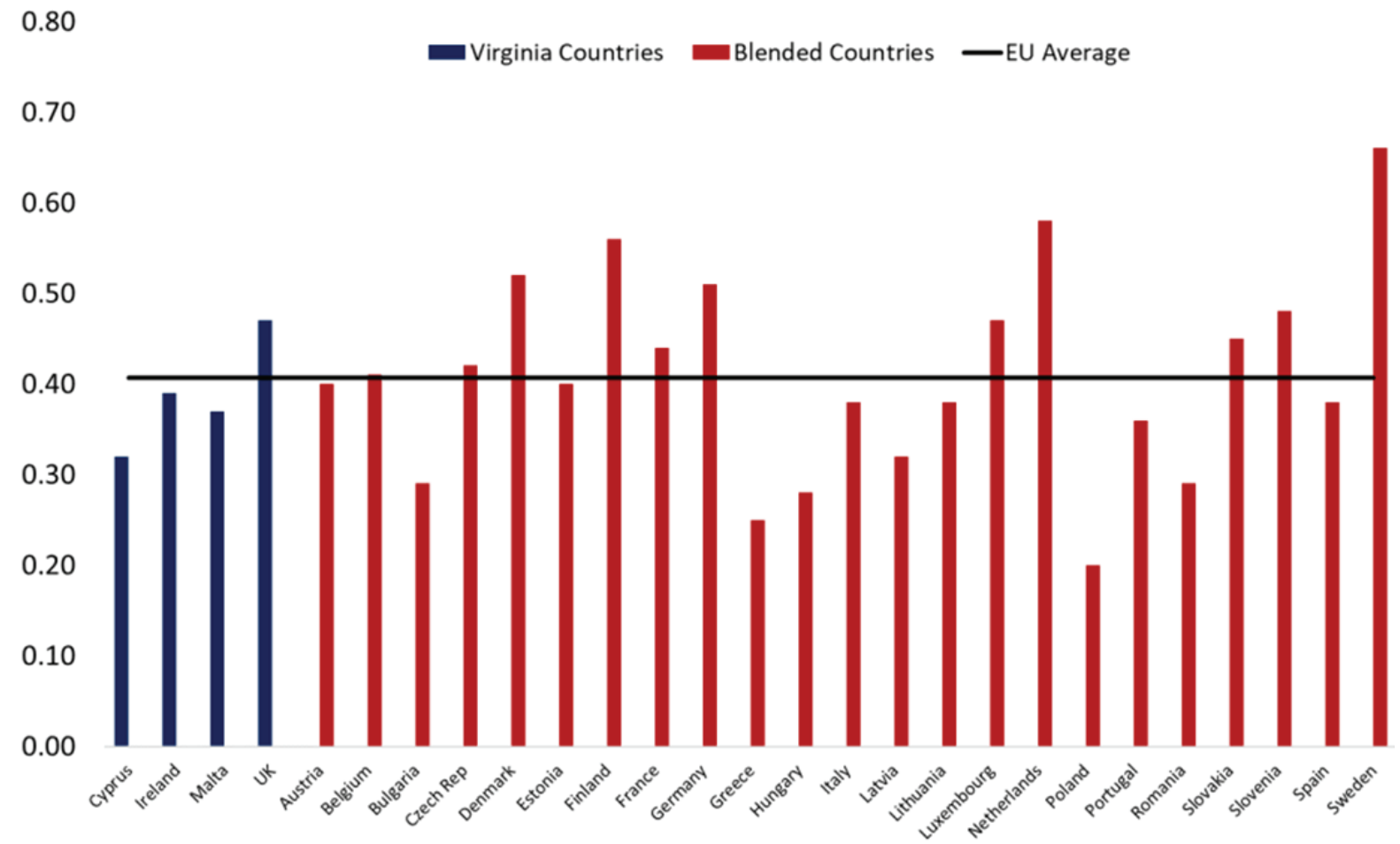

Figure 2c. Quit ratios in EU27 states, 2012 study. 


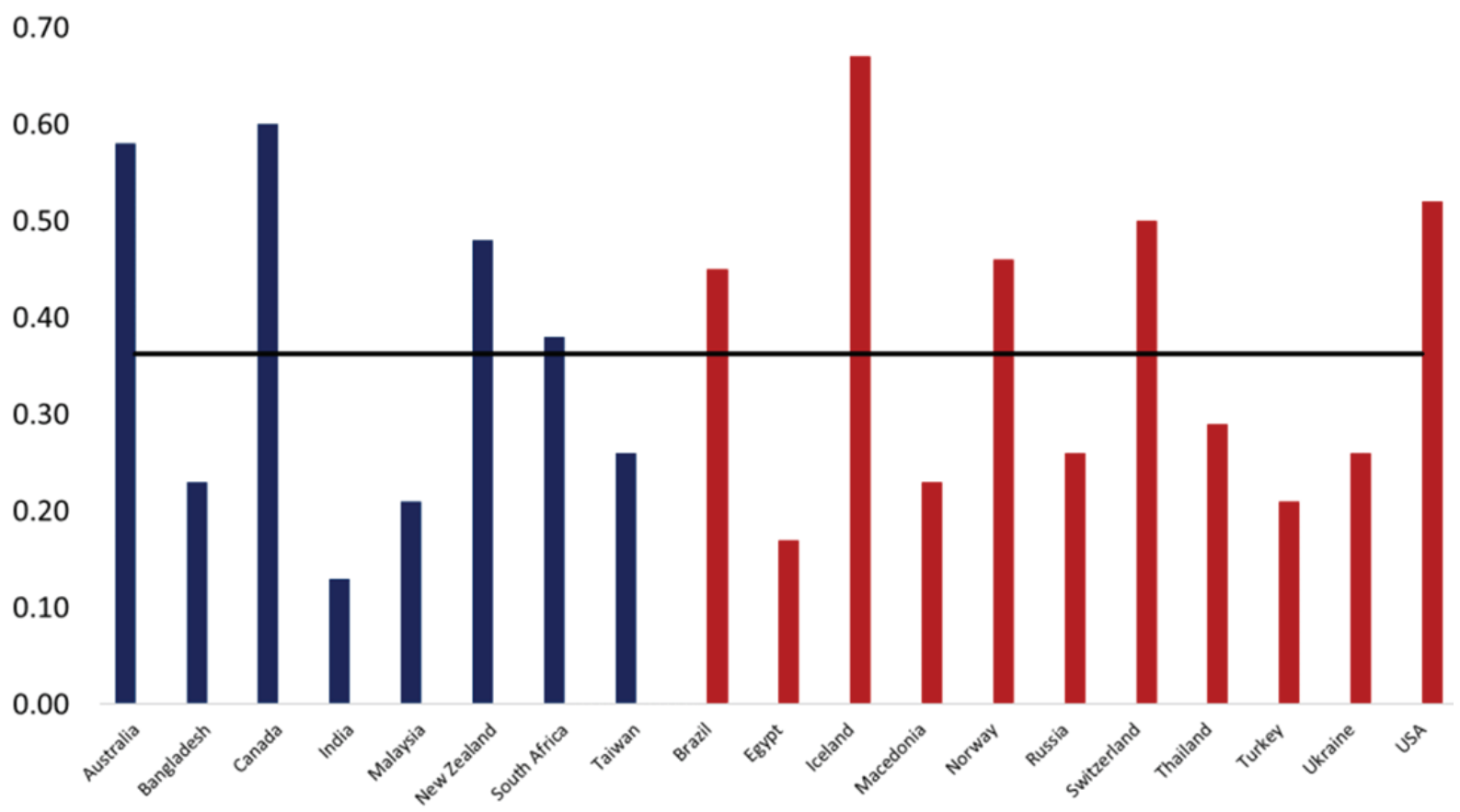

Figure 2d. Quit ratios in non-EU countries, 2012 study.

Table 1. Calculations showing no significant difference in quit ratios between Virginia and blended cigarette markets - with differing market thresholds, 2018 study.

\begin{tabular}{lr}
\hline Total sample (market threshold 50\%) & \\
\hline Mean & 0.349 \\
Standard deviation & 0.158 \\
Observations & 80 \\
\hline Virginia markets (blended share < 50\%) & 0.344 \\
\hline Mean & 0.187 \\
Standard deviation & 18 \\
Observations & \\
\hline Blended markets (blended share $>50 \%)$ & 0.350 \\
\hline Mean & 0.152 \\
Standard deviation & 62 \\
Observations & -0.006 \\
\hline Difference (Virginia - blended) & 0.155 \\
Difference (Virginia - blended) & $+/-1.99$ \\
Critical value & TRUE \\
T-stat < critical value & TRUE \\
Hypothesis: equal means
\end{tabular}

This observation was validated by statistical testing of the means between the two markets (markets in this test are defined as country groups having a majority share of either Virginia-style or traditional blended cigarettes) shown in Table $1^{6}$. Examination using a simple t-test was unable to reject a null hypothesis of no difference in the average quit ratio between the two markets at a 5\%-level of significance. We therefore conclude that the difference in mean quit

6 For the sake of consistency, results in Table 1, and all following tables, treat variables as ratios, rather than percentages. This leads all results and regression coefficients taking values between 0 and 1 .

\begin{tabular}{lr}
\hline Total sample (market threshold 90\%) & \\
\hline Mean & 0.349 \\
Standard deviation & 0.158 \\
Observations & 80 \\
\hline Virginia markets (blended share < 90\%) & 0.319 \\
\hline Mean & 0.175 \\
Standard deviations & 33 \\
Observations & \\
\hline Blended markets (blended share > 90\%) & 0.369 \\
\hline Mean & 0.146 \\
Standard deviations & 47 \\
Observations & -0.050 \\
\hline Difference (Virginia - blended) & 1.40 \\
Difference (Virginia - blended) & $+/-1.99$ \\
Critical value & TRUE \\
T-stat < critical value & TRUE \\
Hypothesis: equal means &
\end{tabular}

ratios between the two subsamples is not statistically significant. It should be noted, however, that the statistical power of this test is limited by the size of our sample and the high variance of the quit ratio across countries in the sample.

Notwithstanding this caveat around statistical power, this result is robust to both different definitions of market predominance, and different specifications of the quit variable. For a test of robustness, we examined whether an effect on quit behaviour in traditional blended markets could be discerned if a more stringent definition of this 
market was used. We therefore recalculated the t-statistic, this time classifying only those countries with a traditional blended market share of greater than $90 \%$ as traditional blended markets, with the remainder classified as Virginia markets. In this case we were still unable to reject the null hypothesis of equal mean quit ratios across the subsamples at the $5 \%$-level of significance.

\subsection{Bivariate and multivariate regression analysis of quit ratios}

The preceding statistical analysis did not take account of other factors that may explain the observed cross-country differences in the quit ratio. We therefore used multivariate regression analysis to control for a range of other variables, including economic and social factors, and thereby investigate whether the residual variation in the quit ratio once these factors have been accounted for has any correlation with the market share of traditional blended cigarettes. We made use of simple linear regression models, estimated using ordinary least squares (OLS); upon examining the residual patterns during the estimation process, we used robust standard errors to combat potential heteroskedasticity. The results of this analysis based on the 2014 data sample (the 2018 study) are presented in Table 2 (for comparison, the results from the 2012 OXFORD ECONOMICS study are presented in the Data Appendices under Table 8). In cases where the sample size is forced to change as new variables are included in the regression and relevant data is not available or not suitable (equations 3, 5, 7 and 10) we run parallel regressions (equations 2, 4, 6 and 9) that are identically specified to the former equation, but with the same sample set as these later regressions. This is to raise comparability between results and highlight the effects of including the new variables on the quit ratio.

A simple univariate model regressing the quit ratio on the percentage share of traditional blended style cigarettes in the domestic market gave a positive coefficient for the blended market share. But this coefficient was not significant at the 5\%-level and the explanatory power of the regression was very low at just 0.05 . This suggests that the market share of traditional blended cigarettes by itself accounts for virtually none of the cross country variation in quit ratios. This supports the conclusion reached in the earlier t-tests, shown in Table 1, which showed no statistically significant difference between quit ratios amongst Virginia-style and traditional blended markets. This conclusion is reinforced by the low $\mathrm{R}^{2}$ of the regression, which illustrates the very limited effect cigarette varieties have on quit ratios globally.

Subsequent iterations of the regression including socioeconomic controls did not change this conclusion. Income is identified in the literaure as having a powerful influence of smoking behavior (REID et al. (9)), so its exclusion might cause biases in a univariate regression. Including the $\log$ of GDP per capita - excluding the outlier of Luxembourg (detailed in Table 5) - turned the coefficient on the share of blended cigarettes negative, but the coefficient was still far from statistically significant ${ }^{7}$. The log of GDP per capita exhibited a strong and statistically significant positive influence on the quit ratio, and raised the $\mathrm{R}^{2}$ to
0.338, suggesting that GDP per capita accounts for a large proportion of cross country variation in quit ratios across time. The explanatory power was further enhanced by the inclusion of an age standardised measure of smoking prevalence, to account for the country's progress along the 'smoking epidemic curve' (LoPEZ et al. (7)). This improved the fit further, with an $\mathrm{R}^{2}$ of 0.559 . The smoking prevalence variable caused only marginal changes in the coefficients while the blended market share coefficient was still not statistically significant at the 5\%-level. The estimated coefficient on log GDP per capita implies that a difference in income per capita of $1 \%$ generates a $0.05-0.09$ rise in the quit ratio. The same coefficient in the 2012 OXFORD ECONOMICS (8) study was a moderately higher $0.12-0.13$.

The effect of income on smoking behaviour is widely regarded as operating via the former's impact on access to education and health information (U.S. NATIONAL CANCER INSTITUTE (15)). There is therefore a possibility that simply using the log of GDP per capita as an explanatory variable is too crude to control for the societal benefits of rising wealth. Better results could perhaps be generated by estimating with these variables directly rather than approximating them through GDP per capita.

Using life expectancy, school enrolment and internet access as controls instead of GDP improves the fit of the equations, but the blended cigarette market share variable remains not significant at the 5\%-level. Combining the blended market share, internet access and the age standardised smoking prevalence produced the strongest result, resulting in an $\mathrm{R}^{2}$ of 0.587 (this was lower than the $\mathrm{R}^{2}$ of 0.75 reported in the 2012 OXFORD ECONOMICS study, which was based on a smaller sample). The market share variable was still not significant in this specification (confirming the results of the 2012 OXFORDECONOMICS Study).

\subsection{Tobacco control measures and quit ratios}

As well as general socio-economic variables such as income and education, much of the existing literature considers variables specific to the tobacco market such as price and non-price tobacco control measures, which have been found to affect smoking behaviour. We proceeded to control for such variables in our regressions, to investigate whether the residual variation in the quit ratio once these factors have been accounted for has any correlation with the market share of traditional blended cigarettes. The results can be found in Table 3 .

The log of the cigarette price demonstrates a high degree of multicollinearity with log GDP per capita, so the two are not included in the same regression. Instead, we run a simple regression of the quit ratio on the log of the cigarette price. This gives a positive and statistically significant coefficient on the latter - with an $\mathrm{R}^{2}$ of 0.592 . The coefficient on the $\log$ of the price implies a $1 \%$-rise in cigarette prices yields a $0.11 \%$-rise in the quit ratio.

To describe the severity of tobacco control policy the Tobacco Control Index (TCI) was constructed. The tobacco control policy data that informed the index was available for 71 countries in 2014. A similar univariate regression of the quit ratio on the Tobacco Control Index gives a coeffi-

\footnotetext{
7 Luxembourg was identified as an outlier in the GDP per capita series using the outlier test demonstrated in Table 5.
} 
Table 2. Linear regressions and coefficients of quit ratio on market share of traditional blended, with socio-economic controls, 2018 study.

\begin{tabular}{|c|c|c|c|c|c|c|c|c|c|c|}
\hline & & Constant & & Independe & it variables & & & & & \\
\hline \multicolumn{11}{|l|}{ Equation 1} \\
\hline QUITR = & & 0.333 & + & 0.022 & ${ }^{*}$ BLEND & & & & & \\
\hline T-statistics & & [8.210] & & [0.445] & & & & & & \\
\hline p-values & & $\left\{0.00^{* * *}\right\}$ & & $\{0.658\}$ & & & & & & \\
\hline R-squared & 0.050 & & & & & & & & & \\
\hline Observations & 80 & & & & & & & & & \\
\hline Degrees of freedom & 79 & & & & & & & & & \\
\hline \multicolumn{11}{|l|}{ Equation 2} \\
\hline QUITR = & & 0.333 & + & 0.02 & ${ }^{*}$ BLEND & & & & & \\
\hline T-statistics & & {$[8.185]$} & & {$[0.398]$} & & & & & & \\
\hline p-values & & $\left\{0.00^{\star * *}\right\}$ & & $\{0.692\}$ & & & & & & \\
\hline R-squared & 0.050 & & & & & & & & & \\
\hline Observations & $79^{\wedge}$ & & & & & & & & & \\
\hline Degrees of freedom & 78 & & & & & & & & & \\
\hline \multicolumn{11}{|l|}{ Equation 3} \\
\hline QUITR = & & -0.138 & + & -0.034 & ${ }^{*}$ BLEND & + & 0.051 & *LOG GDPCAP & & \\
\hline T-statistics & & {$[-0.882]$} & & {$[-0.668]$} & & & [3.100] & & & \\
\hline p-values & & $\{0.380\}$ & & $\{0.506\}$ & & & $\left\{0.003^{* * *}\right\}$ & & & \\
\hline R-squared & 0.338 & & & & & & & & & \\
\hline Observations & $79^{\wedge}$ & & & & & & & & & \\
\hline Degrees of freedom & 78 & & & & & & & & & \\
\hline \multicolumn{11}{|l|}{ Equation 4} \\
\hline QUITR = & & -0.496 & + & -0.07 & ${ }^{*}$ BLEND & + & 0.091 & "LOG GDPCAP & & \\
\hline T-statistics & & {$[-2.645]$} & & {$[-1.456]$} & & & [4.567] & & & \\
\hline p-values & & $\left\{0.010^{* *}\right\}$ & & $\{0.150\}$ & & & $\left\{0.000^{* * *}\right\}$ & & & \\
\hline R-squared & 0.478 & & & & & & & & & \\
\hline Observations & $73^{\wedge \wedge}$ & & & & & & & & & \\
\hline Degrees of freedom & 72 & & & & & & & & & \\
\hline \multicolumn{11}{|l|}{ Equation 5} \\
\hline QUITR = & & -0.407 & + & -0.008 & *BLEND & + & 0.094 & "LOG GDPCAP + & -0.007 & *SPREV \\
\hline T-statistics & & {$[-2.198]$} & & {$[-0.153]$} & & & {$[4.864]$} & & {$[-2.957]$} & \\
\hline p-values & & $\left\{0.031^{\star \star}\right\}$ & & $\{0.879\}$ & & & $\left\{0.000^{\star \star *}\right\}$ & & $\left\{0.004^{\star \star \star}\right\}$ & \\
\hline R-squared & 0.559 & & & & & & & & & \\
\hline Observations & $73^{\wedge \wedge}$ & & & & & & & & & \\
\hline Degrees of freedom & 72 & & & & & & & & & \\
\hline \multicolumn{11}{|l|}{ Equation 6} \\
\hline QUITR = & & -0.434 & + & -0.056 & ${ }^{*}$ BLEND & + & 0.011 & *LIFE & & \\
\hline T-statistics & & {$[-2.018]$} & & {$[-1.097]$} & & & [3.619] & & & \\
\hline p-values & & $\left\{0.047^{\star \star}\right\}$ & & $\{0.276\}$ & & & $\left\{0.001^{* * *}\right\}$ & & & \\
\hline R-squared & 0.384 & & & & & & & & & \\
\hline Observations & 80 & & & & & & & & & \\
\hline Degrees of freedom & 79 & & & & & & & & & \\
\hline \multicolumn{11}{|l|}{ Equation 7} \\
\hline QUITR = & & 0.0591 & + & -0.08 & *BLEND & + & 0.004 & ${ }^{*} \mathrm{SCHOOL}$ & & \\
\hline T-statistics & & {$[0.835]$} & & {$[-1.598]$} & & & [4.505] & & & \\
\hline p-values & & $\{0.406\}$ & & $\{0.114\}$ & & & $\left\{0.000^{* \star *}\right\}$ & & & \\
\hline R-squared & 0.461 & & & & & & & & & \\
\hline Observations & $79^{\wedge \wedge \wedge}$ & & & & & & & & & \\
\hline Degrees of freedom & 78 & & & & & & & & & \\
\hline \multicolumn{11}{|l|}{ Equation 8} \\
\hline QUITR = & & 0.171 & + & -0.057 & ${ }^{*}$ BLEND & + & 0.003 & *INTERNET & & \\
\hline T-statistics & & [3.074] & & {$[-1.153]$} & & & [3.905] & & & \\
\hline p-values & & $\left\{0.003^{* * *}\right\}$ & & $\{0.252\}$ & & & $\left\{0.000^{* * *}\right\}$ & & & \\
\hline R-squared & 0.409 & & & & & & & & & \\
\hline Observations & 80 & & & & & & & & & \\
\hline Degrees of freedom & 79 & & & & & & & & & \\
\hline Equation 9 & & & & & & & & & & \\
\hline QUITR = & & 0.157 & + & -0.08 & *BLEND & + & 0.004 & *INTERNET & & \\
\hline T-statistics & & [2.923] & & {$[-1.656]$} & & & [4.687] & & & \\
\hline$p$-values & & $\left\{0.005^{* * *}\right\}$ & & $\{0.102\}$ & & & $\left\{0.000^{* * *}\right\}$ & & & \\
\hline R-squared & 0.488 & & & & & & & & & \\
\hline Observations & $74^{\wedge \wedge \wedge \wedge}$ & & & & & & & & & \\
\hline Degrees of freedom & 73 & & & & & & & & & \\
\hline Equation 10 & & & & & & & & & & \\
\hline QUITR = & & 0.278 & + & -0.015 & ${ }^{*}$ BLEND & + & 0.004 & *INTERNET & -0.007 & *SPREV \\
\hline T-statistics & & [4.512] & & {$[-0.313]$} & & & [5.335] & & {$[-3.381]$} & \\
\hline p-values & & $\left\{0.000^{* * *}\right\}$ & & $\{0.755\}$ & & & $\left\{0.003^{* * *}\right\}$ & & $\left\{0.001^{* * *}\right\}$ & \\
\hline R-squared & 0.587 & & & & & & & & & \\
\hline Observations & $74^{\wedge \wedge \wedge \wedge}$ & & & & & & & & & \\
\hline Degrees of freedom & 73 & & & & & & & & & \\
\hline
\end{tabular}


Table 3. Linear regressions of quit ratio on tobacco control varieties, 2018 study.

\begin{tabular}{|c|c|c|c|c|c|}
\hline & & Constant & & \multicolumn{2}{|c|}{ Independent variables } \\
\hline \multicolumn{6}{|c|}{ Equation 1} \\
\hline QUITR = & & 0.224 & + & 0.108 & *LOG PRICE \\
\hline T-statistics & & [9.347] & & [6.494] & \\
\hline p-values & & $\left\{0.000^{* * *}\right\}$ & & $\left\{0.000^{* * *}\right\}$ & \\
\hline R-squared & 0.592 & & & & \\
\hline Observations & 80 & & & & \\
\hline Degrees of freedom & 79 & & & & \\
\hline \multicolumn{6}{|l|}{ Equation 2} \\
\hline QUITR = & & 0.233 & + & 0.024 & ${ }^{*} \mathrm{TCl} 1$ \\
\hline T-statistics & & [3.387] & & {$[1.765]$} & \\
\hline p-values & & $\left\{0.001^{* * *}\right\}$ & & $\left\{0.082^{*}\right\}$ & \\
\hline R-squared & 0.208 & & & & \\
\hline Observations & $71^{\wedge}$ & & & & \\
\hline Degrees of freedom & 70 & & & & \\
\hline \multicolumn{6}{|l|}{ Equation 3} \\
\hline QUITR = & & 0.194 & + & 0.031 & ${ }^{*} \mathrm{TCl} 2$ \\
\hline T-statistics & & [2.950] & & [2.481] & \\
\hline$p$-values & & $\left\{0.004^{* * \star}\right\}$ & & $\left\{0.016^{* *}\right\}$ & \\
\hline R-squared & 0.286 & & & & \\
\hline Observations & $71^{\wedge}$ & & & & \\
\hline Degrees of freedom & 70 & & & & \\
\hline \multicolumn{6}{|l|}{ Equation 4} \\
\hline QUITR = & & 0.477 & + & -0.005 & *BUDGETRANK \\
\hline T-statistics & & [11.042] & & {$[-3.336]$} & \\
\hline p-values & & $\left\{0.000^{\star * \star}\right\}$ & & $\left\{0.002^{\star \star *}\right\}$ & \\
\hline R-squared & 0.420 & & & & \\
\hline Observations & $54^{\wedge \wedge}$ & & & & \\
\hline Degrees of freedom & 53 & & & & \\
\hline
\end{tabular}

* significant at $10 \%$ level, p-value below 0.1 ; ** significant at $5 \%$ level, p-value below 0.05 ; *** significant at $1 \%$ level, p-value below 0.01 $\wedge^{\wedge}$ Excluding Iran, Mexico, Moldova, South Korea, Taiwan, UAE, USA, Venzuela, and Vietnam (no data)

$\wedge \wedge$ Excluding Bahrain, Belarus, Costa Rica, Czech Rep., Estonia, Georgia, Greece, Hungary, Ireland, Luxembourg, Malaysia, Morocco, Norway, Panama, Portugal, Russia, Singapore, Spain, Switzerland, Taiwan, Tunisia, UAE, Uganda, Ukraine, Uruguay and UK (no data)

cient on the latter that is insignificant at the 5\%-level, with an $\mathrm{R}^{2}$ of 0.208 . However, a 'stripped down' version of the index that used only the most effective policies for smoking cessation, using smoke-free areas, health warnings and cessation program subcomponents of the index, results in a positive and significant coefficient, with a slightly higher $\mathrm{R}^{2}$ of 0.286 . Details on the Tobacco Control Index can be found in Table 6 .

Finally, a regression of the quit ratio on our control budget rank variable produced a negative and statistically significant coefficient with an $\mathrm{R}^{2}$ of 0.420 . This is what we would expect, as greater government efforts to warn of the hazards of smoking would lead to a rise in the quit ratio across the selected country.

\section{DISCUSSION}

We have investigated the hypothesis that the use of ingredients, including flavours, in traditional blended cigarettes affects quit behaviour among smokers. To that end, we compared countries with a high market share of traditional blended cigarettes, made with ingredients added to tobacco, and Virginia-style cigarettes, made with very few or no ingredients added to tobacco. We found no statistically significant difference in mean quit ratios between predominantly Virginia-style markets and predo- minantly traditional blended markets. This is in line with existing cross-country studies, such as that by SANDERS et al. (12), which analysed data from clinical trials over the last three decades and across seven countries, and found that the use of ingredients did not increase the addictiveness of cigarettes.

The findings were robust to both domestic market dominance and controls on the various socio-economic or tobacco policy factors that shape rates of cessation across countries. Raw correlation variables between market dominance and quit ratios was found to be very small. Thus, almost none of the cross-country variation in quit ratios was attributable to the dominance of blended cigarettes in the domestic market.

There are limitations to this purely cross-sectional analysis, as the conclusions reached may not apply across different time periods. On the other hand, this concern may be mitigated to some degree by the fact that the same conclusion was reached by the 2012 OxFORD ECONOMICS (8) study, and the stability of smoking patterns across time.

We found that socio-economic variables exhibited a statistically significant relationship with cessation rates, accounting for a large part of international variation in quit rates. This result is in accordance with existing literature. The countries with the highest quit ratios are generally more economically developed: high GDP per capita has a close positive correlation with education and health indi- 
cators, as well as tobacco control policies (YAMANAKA et al. (18)). The impact on quit behaviour of these socioeconomic and tobacco policy variables is substantial. None of the regressions specified in this paper show a significant change in the quit ratio related to the use of cigarette ingredients.

Economic variables such as national income per capita exerted a moderately lower influence on cessation rates in this study, relative to the 2012 study. This may be attributed to the inclusion of a broader sample of less developed countries in the 2018 study, leading to increased in-sample variation in the societal and cultural variables that affect smoking cessation. This more complete picture of global smoking patterns across richer and poorer countries lends greater credibility to the results from this study. On the other hand, the wider global sample in this study exposes the regression to higher levels of countryspecific (idiosyncratic) variation in the quit ratio that are not explained by the dependent variables in the regression model. This may explain the comparatively lower level of $\mathrm{R}^{2}$ in our regressions. Still, whilst the $\mathrm{R}^{2}$ terms may differ between the two analyses, the broad consistency in magnitude of the coefficients across both the 2018 and 2012 studies give us confidence that our results are not skewed by any sample specific difficulties.

\section{CONCLUSIONS}

Our cross-country study of cessation rates (80 countries) support the findings of the 2012 study (46 countries) that there is no statistical evidence to support the hypothesis that ingredients used in traditional blended cigarettes affect smoking cessation patterns. Socio-economic variables (such as internet access) and tobacco control variables had a significant effect on the quit ratio, accounting for much of the cross-country variation in smoking cessation rates. This is in line with the existing literature, which indicates that economic development and corresponding improvements in access to education and health information are associated with higher quit ratios. With the increased use of ecigarettes, the structure of this relationship may change in the future, so an area of future research may be to investigate the influence of e-cigarettes on national quit ratios.

\section{CONFLICT OF INTEREST STATEMENT}

The funding for this work was provided by Philip Morris International.

\section{REFERENCES}

1. Fisher, P.: Tobacco Blending; in Tobacco: Production, Chemistry and Technology, edited by D.L. Davis and M.T. Nielsen, Blackwell Science, Oxford, UK, 1999, pp. 346-352. ISBN: 0-632-04791-7

2. Nair, U.: Additives in Tobacco Products. Contribution of Carob Bean Extract, Cellulose Fibre, Guar Gum, Liquorice, Menthol, Prune Juice Concentrate and Vanillin to Attractiveness, Addictiveness and Toxicity of Tobacco Smoking; German Cancer Research Center, Heidelberg, Germany, 2012. Available at: https://www.dkfz.de/de/tabakkontrolle/download/PIT OC/PITOC_Additives_in_Tobacco_Products_Report. pdf (accessed July 2018)

3. Joossens, L. and M. Raw: The Tobacco Control Scale: A New Scale to Measure Country Activity; Tob. Control 15 (2006) 247-253.

DOI: $10.1136 /$ tc. 2005.015347

4. Joossens, L. and M. Raw: The Tobacco Control Scale 2010 in Europe. A Report of the Association of European Cancer Leagues; Brussels, Belgium, 2010. Available at: https:/www.krebshilfe.de/fileadmin/ Downloads/PDFs/Kampagnen/TCS_2010_Europe.pdf (accessed July 2018)

5. Keeler, T.E., T.-W. Hu, P.G. Barnett, and G.W. Manning: Taxation, Regulation, and Addiction: A Demand Function for Cigarettes Based on Time Series Evidence; J. Health Econ. 12 (1993) 1-18. DOI: 10.1016/0167-6296(93)90037-F

6. Lee, P.N., B.A. Forey, J.S. Fry, J.S. Hamling, J.F. Hamling, E.B. Sanders, and R.A. Carchman: Does Use of Flue-Cured Rather Than Blended Cigarettes Affect International Variation in Mortality From Lung Cancer and COPD?; Inhal. Toxicol. 21 (2009) 404-430. DOI: $10.1080 / 08958370802317737$

7. Lopez, A.D., N.E. Collishaw, and T. Piha: A Descriptive Model of the Cigarette Epidemic in Developed Countries; Tob. Control 3 (1994) 242-247. Available at: https://www.ncbi.nlm.nih.gov/pmc/articles/PMC 1759359/pdf/v003p00242.pdf (accessed July 2018)

8. Oxford Economics: The Impact of Cigarette Ingredients on Quit Ratios; Oxford, UK, February 2012. Available at: www.oxfordeconomics.com/publication/open/ 243949 (accessed July 2018)

9. Reid, J.L., D. Hammond, C. Boudreau, G.T. Fong, and M. Siahpush: Socioeconomic Disparities in Quit Intentions, Quit Attempts, and Smoking Abstinence Among Smokers in Four Western Countries: Findings From the International Tobacco Control Four Country Survey; Nicotine Tob. Res. 12 (2010) S20-33. DOI: $10.1093 /$ ntr/ntq051

10. Ross, H. and F.J. Chaloupka: The Effect of Cigarette Prices on Youth Smoking; Health Econ. 12 (2003) 217-230. DOI: 10.1002/hec.709

11. Schaap, M.M., A.E. Kunst, M. Leinsalu, E. Regidor, O. Ekholm, D. Dzurova, U. Helmert, J. Klumbiene, P. Santana, and J.P. Mackenbach: Effect of Nationwide Tobacco Control Policies on Smoking Cessation in High and Low Educated Groups in 18 European Countries; Tob. Control 1 (2009) 248-255.

DOI: $10.1136 /$ tc. 2007.024265

12. Sanders, E., R. Weitkunat, A. Utan, and R. Dempsey: Does the Use of Ingredients Added to Tobacco Increase Cigarette Addictiveness?: A Detailed Analysis; Inhal. Toxicol. 24 (2012) 227-245. DOI: $10.3109 / 08958378.2012 .663006$

13. SCENIHR (Scientific Committee on Emerging and Newly Identified Health Risks): Addictiveness and Attractiveness of Tobacco Additives; European Commission, Directorate General for Health and Consumers, 2010. Available at: https://ec.europa.eu/ 
health/scientific_committees/emerging/docs/scenihr_o_ 029.pdf (accessed July 2018)

14. Sung, H.Y., T.-W. Hu, and T.E. Keeler: Cigarette Taxation and Demand: An Empirical Model; Contemp. Econ. Policy 12 (1994) 91-100. DOI: $10.1111 / \mathrm{j} .1465-7287.1994 . t b 00437 . x$

15. U.S. Department of Health and Human Services: Those Who Continue to Smoke; Monograph 15, National Institues of Health, National Cancer Institute, 2003. Available at: https://cancercontrol.cancer.gov/brp/tcrb/ monographs/15/monograph15.pdf (accessed July 2018)

16. World Health Organization (WHO): Global Health Observatory Data Repository; 3.a Tobacco Control, WHO. Available at: http://apps.who.int/gho/data/node. home (accessed July 2018)

17. The World Bank: Development Indicators; The World Bank Group DataBank. Available at: http://databank. worldbank.org/data/reports.aspx ? source $=$ WorldDevelopment-Indicators (accessed July 2018)

18. Yamanaka, K., M. Miyao, T.-A. Kondo, H. Sakakibara, M. Furuta, K. Tahiki, and S. Yamada: An International Analysis of Smoking Control Levels in Relation to Health, Social and Economic Indicators; Nagoya J. Med. Sci. 56 (1993) 101-110. Available at: http://jairo.nii.ac.jp/0002/00012770/en (accessed July 2018)

Corresponding author:

Matthew Rodger

Oxford Economics Ltd.

Abbey House, 121 St Aldates

Oxford $O X 11 \mathrm{HB}$

United Kinddom

E-mail:mrodger@oxfordeconomics.com

\section{DATA APPENDIX}

As specified in the estimated regressions, quit ratios vary dramatically across countries largely due to socio-economic factors. These variables, including GDP per capita, life expectancy and internet access, can be taken as proxies for the wealth of a country, the availability of information and the extent of healthcare coverage. Variations in these fundamental factors drive differences in the quit ratio between countries in our sample.

Table 5. GDP per capita outlier test, 2018 study.

\begin{tabular}{lc}
\hline Series & GDP per capita \\
\hline Average & 30965 \\
1st Quartile & 12961 \\
3rd Quartile & 43671 \\
Inter-quartile range & 30710 \\
Upper bound $^{\wedge}$ & 89736 \\
Lower bound $^{\wedge} \wedge$ & -33105 \\
Luxembourg GDPCAP & 102389 \\
Outlier & TRUE \\
\hline
\end{tabular}

$\wedge$ Defined as $3^{\text {rd }}$ Quartile adding $1.5^{*}$ Inter-Quartile range

$\wedge \wedge$ Defined as $1^{\text {st }}$ Quartile subtracting $1.5^{*}$ Inter-Quartile range 
Table 4. Quit ratio variable, blended market share and sources, 2018 study.

\begin{tabular}{|c|c|c|c|c|c|c|c|}
\hline Country & $\begin{array}{l}\text { Quit } \\
\text { ratio }^{a} \\
(\%)\end{array}$ & $\begin{array}{c}\text { Traditional } \\
\text { blended } \\
\text { market } \\
\text { share }^{\mathrm{b}}(\%)\end{array}$ & Data source & Country & $\begin{array}{l}\text { Quit } \\
\text { ratio }^{a} \\
(\%)\end{array}$ & $\begin{array}{c}\text { Traditional } \\
\text { blended } \\
\text { market } \\
\text { share }^{\mathrm{b}}(\%) \\
\end{array}$ & Data source \\
\hline Argentina* & 40 & 89 & WHO GATS & Luxembourg & 45 & 97 & Eurobarometer 385 \\
\hline Armenia* & 19 & 98 & GILMORE et al. 2004 & Malaysia & 10 & 37 & $\begin{array}{l}\text { National Health \& Morbidity Survey } \\
2015\end{array}$ \\
\hline Australia & 60 & 4 & $\begin{array}{l}\text { Tobacco in Australia } \\
\text { 2017: Cancer Council of } \\
\text { Victoria }\end{array}$ & Malta & 39 & 20 & Eurobarometer 385 \\
\hline Austria & 40 & 96 & Eurobarometer 385 & Mexico* & 36 & 97 & WHO GATS \\
\hline Bahrain* & 57 & 54 & AHMED et al. 2017 & Moldova* & 24 & 95 & GILMORE et al. 2004 \\
\hline Bangladesh & 18 & 0 & WHO GATS & Mongolia* & 65 & 64 & BAIGALMAA et al. 2006 \\
\hline Belarus* & 20 & 99 & GILMORE et al. 2004 & Morocco* & 31 & 84 & BERRAHO et al. 2008 \\
\hline Belgium & 43 & 96 & Eurobarometer 385 & Netherlands & 56 & 98 & Eurobarometer 385 \\
\hline Brazil & 47 & 98 & WHO GATS & New Zealand & 61 & 6 & $\begin{array}{l}\text { NZ Ministry of Health: Tobacco Use } \\
\text { Survey } 2016\end{array}$ \\
\hline Bulgaria & 31 & 92 & Eurobarometer 385 & Nigeria* & 27 & 1 & WHO GATS \\
\hline Cameroon* & 33 & 0 & WHO GATS & Norway & 46 & 100 & Eurobarometer 385 \\
\hline Canada & 68 & 1 & $\begin{array}{l}\text { Tobacco Use in Canada: } \\
2017 \text { edition }\end{array}$ & Pakistan* & 8 & 1 & WHO GATS \\
\hline Chile* & 14 & 100 & PusCHEL et al. 2008 & Panama* & 37 & 100 & WHO GATS \\
\hline China* & 10 & 5 & YANG et al. 2001 & Philippines* & 19 & 99 & WHO GATS \\
\hline Costa Rica* & 57 & 100 & WHO GATS & Poland & 38 & 97 & Eurobarometer 385 \\
\hline Cyprus & 43 & 84 & Eurobarometer 385 & Portugal & 39 & 95 & Eurobarometer 385 \\
\hline Czech Rep. & 37 & 98 & Eurobarometer 385 & Qatar* & 17 & 69 & WHO GATS \\
\hline Denmark & 54 & 94 & Eurobarometer 385 & Romania & 29 & 99 & Eurobarometer 385 \\
\hline Egypt & 17 & 100 & WHO GATS & Russia & 18 & 97 & WHO GATS \\
\hline Estonia & 45 & 100 & Eurobarometer 385 & Saudi Arabia* & 25 & 78 & BCHERAOUI et al. 2015 \\
\hline Finland & 47 & 100 & Eurobarometer 385 & Senegal* & 51 & 38 & WHO GATS \\
\hline France & 46 & 90 & Eurobarometer 385 & Singapore* & 33 & 85 & ZOE et al. 2004 \\
\hline Georgia* & 12 & 97 & GILMORE et al. 2004 & Slovakia & 40 & 99 & Eurobarometer 385 \\
\hline Germany & 50 & 98 & Eurobarometer 385 & Slovenia & 40 & 98 & Eurobarometer 385 \\
\hline Greece & 29 & 91 & Eurobarometer 385 & South Africa & 38 & 13 & $\begin{array}{l}\text { South African Demographic \& } \\
\text { Health Survey } 2003\end{array}$ \\
\hline Hungary & 32 & 98 & Eurobarometer 385 & Spain & 40 & 91 & Eurobarometer 385 \\
\hline Iceland & 68 & 97 & $\begin{array}{l}\text { Public Health Institute of } \\
\text { Iceland } 2016\end{array}$ & Sweden & 70 & 100 & Eurobarometer 385 \\
\hline India & 13 & 1 & WHO GATS & Switzerland & 50 & 93 & CHIOLORO et al. 2007 \\
\hline Iran* & 18 & 52 & HEYDARI et al. 2011 & Taiwan & 26 & 52 & Taiwan Adult Tobacco Survey 2006 \\
\hline Ireland & 40 & 26 & Eurobarometer 385 & Thailand & 27 & 100 & WHO GATS \\
\hline Italy & 35 & 100 & Eurobarometer 385 & Tunisia* & 10 & 77 & SAHLI et al. 2017 \\
\hline Japan* & 14 & 98 & TABUCHI et al. 2016 & Turkey & 27 & 99 & Eurobarometer 385 \\
\hline Jordan* & 9 & 100 & JAGHBIR et al. 2014 & $\mathrm{UAE}^{*}$ & 17 & 76 & Dubai Health Authority 2015 \\
\hline Kazakhstan* & 13 & 88 & GILMORE et al. 2004 & Uganda* & 43 & 0 & WHO GATS \\
\hline Kenya* & 29 & 1 & WHO GATS & UK & 29 & 97 & Eurobarometer 385 \\
\hline Rep. Korea* & 42 & 90 & HEE-KIM et al. 2015 & Ukraine & 49 & 26 & WHO GATS \\
\hline Kuwait* & 25 & 80 & OMu et al. 2015 & Uruguay* $^{*}$ & 42 & 100 & WHO GATS \\
\hline Kyrgyzstan* & 15 & 90 & GILMORE et al. 2004 & USA & 63 & 100 & NHIS Survey 2016 \\
\hline Latvia & 31 & 100 & Eurobarometer 385 & Venezuela* & 51 & 95 & BERMUDEZ et al. 2016 \\
\hline Lithuania & 33 & 100 & Eurobarometer 385 & Vietnam* & 25 & 2 & WHO GATS \\
\hline
\end{tabular}

* Country has been newly included in the sample

a Share of former smokers in ever-smokers (current smokers + former smokers; ${ }^{\mathrm{b}}$ Data provided by AC Nielsen and PMI 
Table 6. Tobacco Control Index, 2018 study.

\begin{tabular}{|c|c|c|c|c|c|c|}
\hline \multicolumn{7}{|c|}{ Tobacco Control Index (TCl) and sub components scores } \\
\hline Country & $\begin{array}{c}\text { Tobacco Control } \\
\text { Index } 1(\mathrm{TCl} 1)(\%) \\
\end{array}$ & $\begin{array}{c}\text { Tobacco Control } \\
\text { Index } 2(\mathrm{TCl} 2)(\%)\end{array}$ & 1. Smoke free & $\begin{array}{l}\text { 2. Advertisement } \\
\text { ban }\end{array}$ & 3. Cessation & $\begin{array}{l}\text { 4. Health } \\
\text { warnings }\end{array}$ \\
\hline Argentina & 4.4 & 4.3 & 5 & 3 & 3 & 5 \\
\hline Armenia & 5.0 & 4.3 & 5 & 6 & 5 & 3 \\
\hline Australia & 7.2 & 7.7 & 5 & 6 & 9 & 9 \\
\hline Austria & 3.3 & 3.7 & 0 & 3 & 6 & 5 \\
\hline Bahrain & 3.9 & 3.7 & 3 & 6 & 6 & 2 \\
\hline Bangladesh & 2.9 & 3.0 & 1 & 3 & 3 & 5 \\
\hline Belarus & 3.8 & 4.3 & 3 & 6 & 5 & 5 \\
\hline Belgium & 6.2 & 7.3 & 6 & 3 & 9 & 7 \\
\hline Brazil & 6.2 & 6.3 & 1 & 4 & 9 & 9 \\
\hline Bulgaria & 4.0 & 4.7 & 3 & 5 & 6 & 5 \\
\hline Cameroon & 5.6 & 6.0 & 5 & 6 & 7 & 6 \\
\hline Canada & 5.7 & 7.0 & 9 & 7 & 3 & 9 \\
\hline Chile & 7.0 & 6.3 & 8 & 5 & 5 & 6 \\
\hline China & 3.8 & 4.7 & 3 & 5 & 5 & 6 \\
\hline Costa Rica & 6.7 & 6.3 & 7 & 7 & 6 & 6 \\
\hline Cyprus & 3.6 & 5.7 & 6 & 5 & 6 & 5 \\
\hline Czech Republic & 2.5 & 3.3 & 2 & 3 & 3 & 5 \\
\hline Denmark & 6.2 & 6.3 & 6 & 9 & 6 & 7 \\
\hline Egypt & 6.2 & 5.7 & 2 & 8 & 6 & 9 \\
\hline Estonia & 2.9 & 3.0 & 1 & 3 & 3 & 5 \\
\hline Finland & 6.3 & 6.7 & 9 & 6 & 6 & 5 \\
\hline France & 6.1 & 6.7 & 6 & 5 & 9 & 5 \\
\hline Georgia & 5.0 & 4.3 & 5 & 6 & 5 & 3 \\
\hline Germany & 3.8 & 4.3 & 2 & 3 & 6 & 5 \\
\hline Greece & 4.0 & 4.0 & 4 & 5 & 3 & 5 \\
\hline Hungary & 3.3 & 3.0 & 1 & 5 & 3 & 5 \\
\hline Iceland & 3.5 & 3.7 & 3 & 3 & 3 & 5 \\
\hline India & 3.2 & 2.3 & 2 & 5 & 3 & 2 \\
\hline Ireland & 6.5 & 7.7 & 9 & 3 & 9 & 5 \\
\hline Italy & 6.0 & 6.0 & 7 & 7 & 6 & 5 \\
\hline Japan & 3.7 & 3.7 & 3 & 6 & 5 & 3 \\
\hline Jordan & 5.1 & 5.3 & 5 & 5 & 5 & 6 \\
\hline Kazakhstan & 4.5 & 5.0 & 4 & 6 & 5 & 6 \\
\hline Kenya & 4.8 & 5.7 & 4 & 7 & 6 & 7 \\
\hline Kuwait & 7.0 & 6.3 & 7 & 8 & 7 & 5 \\
\hline Kyrgyzstan & 5.6 & 6.0 & 5 & 6 & 7 & 6 \\
\hline Latvia & 2.9 & 3.0 & 1 & 3 & 3 & 5 \\
\hline Lithuania & 4.5 & 4.3 & 2 & 6 & 6 & 5 \\
\hline Luxembourg & 5.1 & 5.3 & 5 & 6 & 5 & 6 \\
\hline Malaysia & 6.5 & 5.3 & 1 & 4 & 6 & 9 \\
\hline Malta & 3.7 & 4.0 & 1 & 3 & 6 & 5 \\
\hline Mongolia & 7.1 & 6.7 & 7 & 6 & 8 & 5 \\
\hline Morocco & 4.7 & 5.0 & 5 & 3 & 4 & 6 \\
\hline Netherlands & 3.1 & 3.3 & 2 & 2 & 3 & 5 \\
\hline New Zealand & 8.2 & 9.0 & 9 & 6 & 9 & 9 \\
\hline Nigeria & 4.8 & 4.3 & 5 & 6 & 4 & 4 \\
\hline Norway & 4.3 & 4.3 & 2 & 5 & 6 & 5 \\
\hline Pakistan & 4.7 & 5.0 & 4 & 6 & 6 & 5 \\
\hline Panama & 6.1 & 6.3 & 6 & 7 & 6 & 7 \\
\hline Philippines & 5.1 & 5.3 & 5 & 6 & 5 & 6 \\
\hline Poland & 4.6 & 4.0 & 1 & 7 & 6 & 5 \\
\hline Portugal & 4.9 & 5.0 & 4 & 5 & 6 & 5 \\
\hline Qatar & 4.0 & 5.0 & 3 & 5 & 6 & 6 \\
\hline Romania & 5.7 & 5.7 & 1 & 6 & 9 & 7 \\
\hline Russia & 1.5 & 1.7 & 0 & 1 & 3 & 2 \\
\hline Saudi Arabia & 5.6 & 4.7 & 6 & 6 & 5 & 3 \\
\hline Senegal & 6.3 & 6.0 & 7 & 3 & 5 & 6 \\
\hline Singapore & 6.3 & 6.7 & 5 & 9 & 9 & 6 \\
\hline Slovakia & 4.5 & 4.7 & 3 & 5 & 6 & 5 \\
\hline Slovenia & 4.2 & 4.7 & 3 & 4 & 6 & 5 \\
\hline South Africa & 3.7 & 2.3 & 2 & 8 & 3 & 2 \\
\hline Spain & 4.5 & 4.0 & 4 & 7 & 3 & 5 \\
\hline Sweden & 4.2 & 4.7 & 3 & 4 & 6 & 5 \\
\hline Switzerland & 3.6 & 4.3 & 0 & 2 & 6 & 7 \\
\hline Thailand & 5.3 & 5.7 & 2 & 5 & 6 & 9 \\
\hline Tunisia & 3.3 & 4.0 & 3 & 5 & 3 & 6 \\
\hline Turkey & 5.0 & 4.3 & 5 & 8 & 3 & 5 \\
\hline Uganda & 4.9 & 4.3 & 5 & 4 & 5 & 3 \\
\hline Ukraine & 2.3 & 2.7 & 0 & 2 & 3 & 5 \\
\hline UK & 7.0 & 8.3 & 9 & 3 & 9 & 7 \\
\hline Uruguay & 4.3 & 4.7 & 4 & 4 & 5 & 5 \\
\hline
\end{tabular}


Table 7. Quit ratio variable, blended market share and sources, 2012 study.

\begin{tabular}{|c|c|c|c|}
\hline Country & $\begin{array}{c}\text { Quit ratio }^{a} \\
(\%)\end{array}$ & $\begin{array}{c}\text { Trad. blended market } \\
\text { share }^{\mathrm{b}}(\%)\end{array}$ & Data source \\
\hline Australia & 58 & 8 & Tobacco in Australia: Cancer Council of Victoria \\
\hline Austria & 40 & 97 & Eurobarometer 332 \\
\hline Bangladesh & 23 & 0 & WHO GATS \\
\hline Belgium & 41 & 90 & Eurobarometer 332 \\
\hline Brazil & 45 & 100 & WHO GATS \\
\hline Bulgaria & 29 & 65 & Eurobarometer 332 \\
\hline Canada & 60 & 1 & Tobacco Use in Canada 2011 Edition \\
\hline Cyprus & 32 & 35 & Eurobarometer 332 \\
\hline Czech Republic & 42 & 95 & Eurobarometer 332 \\
\hline Denmark & 52 & 82 & Eurobarometer 332 \\
\hline Egypt & 17 & 98 & WHO GATS \\
\hline Estonia & 40 & 100 & Eurobarometer 332 \\
\hline Finland & 56 & 100 & Eurobarometer 332 \\
\hline France & 44 & 85 & Eurobarometer 332 \\
\hline Germany & 51 & 97 & Eurobarometer 332 \\
\hline Greece & 25 & 92 & Eurobarometer 332 \\
\hline Hungary & 28 & 100 & Eurobarometer 332 \\
\hline Iceland & 67 & 100 & Public Health Institute of Iceland 2009 \\
\hline India & 13 & 0 & WHO GATS \\
\hline Ireland & 39 & 13 & Eurobarometer 332 \\
\hline Italy & 38 & 99 & Eurobarometer 332 \\
\hline Latvia & 32 & 100 & Eurobarometer 332 \\
\hline Lithuania & 38 & 100 & Eurobarometer 332 \\
\hline Luxembourg & 47 & 92 & Eurobarometer 332 \\
\hline Macedonia & 23 & 83 & Eurobarometer 332 \\
\hline Malaysia & 21 & 41 & National Health and Morbidity Survey 2006 \\
\hline Malta & 37 & 13 & Eurobarometer 332 \\
\hline Netherlands & 58 & 92 & Eurobarometer 332 \\
\hline New Zealand & 48 & 5 & NZ Ministry of Health Tobacco use survey 2009 \\
\hline Norway & 46 & 100 & Eurobarometer 332 \\
\hline Poland & 20 & 88 & Eurobarometer 332 \\
\hline Portugal & 36 & 97 & Eurobarometer 332 \\
\hline Romania & 29 & 97 & Eurobarometer 332 \\
\hline Russia & 26 & 96 & WHO GATS \\
\hline Slovakia & 45 & 100 & Eurobarometer 332 \\
\hline Slovenia & 48 & 94 & Eurobarometer 332 \\
\hline South Africa & 38 & 24 & South African Demographic \& Health Survey \\
\hline Spain & 38 & 86 & Eurobarometer 332 \\
\hline Sweden & 66 & 100 & Eurobarometer 332 \\
\hline Switzerland & 50 & 90 & CHIOLORO et al. 2007 \\
\hline Taiwan & 26 & 41 & Taiwan Adult Tobacco Survey 2006 \\
\hline Thailand & 29 & 94 & WHO GATS \\
\hline Turkey & 21 & 97 & Eurobarometer 332 \\
\hline UK & 47 & 8 & Eurobarometer 332 \\
\hline Ukraine & 26 & 92 & WHO GATS \\
\hline USA & 52 & 100 & NHIS Survey 2009 \\
\hline
\end{tabular}

a Share of former smokers in ever-smokers (current + former smokers)

b Data provided by AC Nielsen and PMI 
Table 8. Linear regressions of quit ratio on market share of traditional blended, with socio-economic controls, 2012 study.

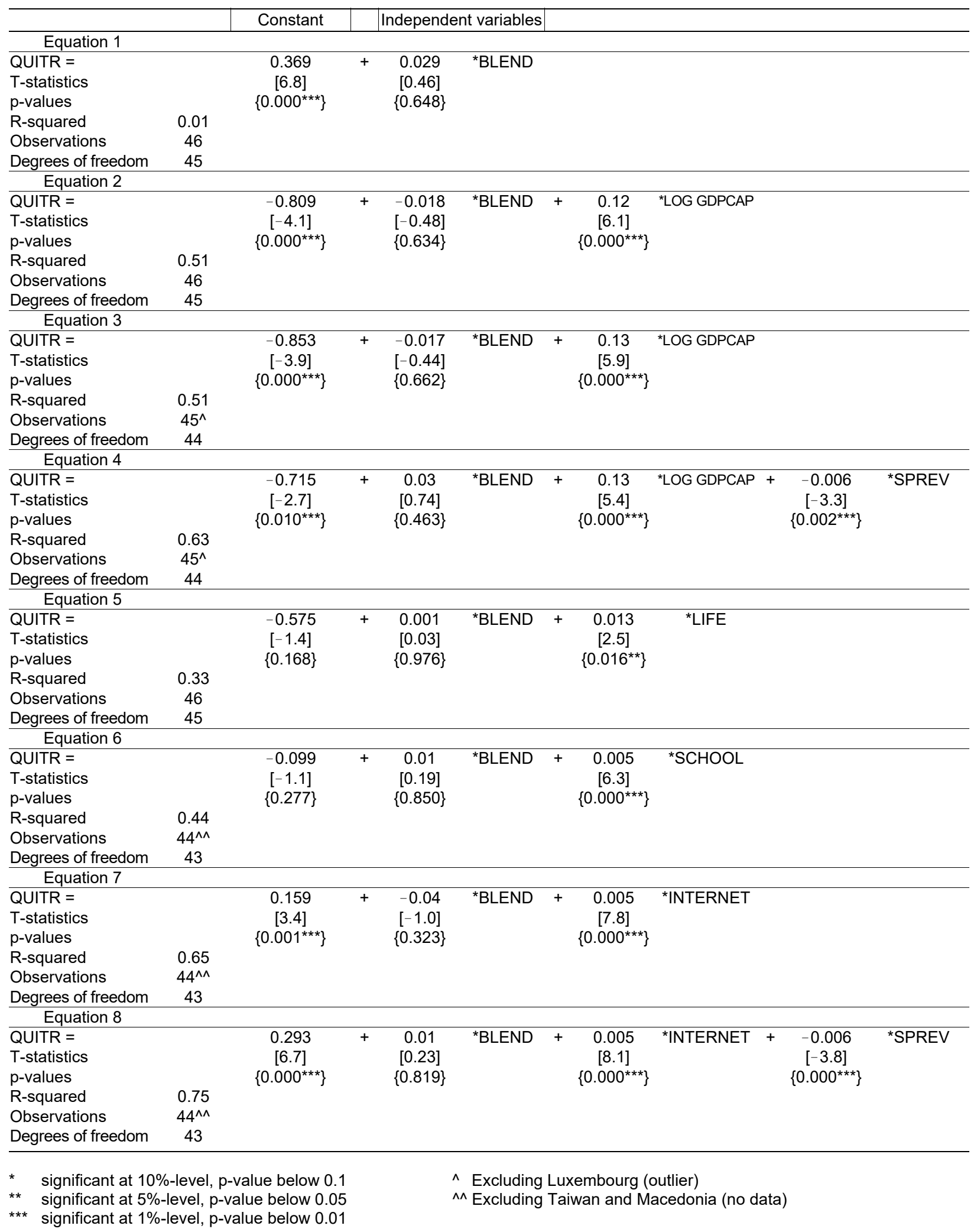

